This Journal is available in Telkom University online Journals

Jurnal Manajemen Indonesia

\title{
Analysis of Innovation Strategies to Improve the Quality of Infrastructure in Public Organisation using the Technical Evaluation and Decision Square (TEDS) Method
}

\author{
A. Hafiz Rahman ${ }^{1 *}$, B. Sri Oktavia ${ }^{2}$, C. Yogi Irvanda ${ }^{3}$ \\ ${ }^{1,3}$ Department of Management, Faculty of Economics, Universitas Andalas, Padang, Indonesia \\ ${ }^{2}$ Faculty of Law Universitas Andalas, Padang, Indonesia
}

\begin{abstract}
This paper aims to analyze and discuss the implementation of innovative strategies in a public higher education institution in Indonesia. Analysis is undertaken by using Total Evaluation and Decision Square (TEDS) Method, which employs [a] Total Financial Management (TFM), [b] Total Content Management (TCM), [c] Total Process and Project Management (TPPM), and [d] Total Stakeholder Management (TSM) as the focus of analysis. This is a qualitative study with the descriptive approach. Data and information were collected by using in-depth interview to the dean of the faculty and leaders of the department in the faculty. Results of the interview were further analysed by using thematic analysis to get insights related to the topic of study. It can be inferred that the institution has already undertaken positive and beneficial innovation strategies. However, they are not effectively undertaken. This can be seen in the results of this study which show positive indicators in the parameters of Total Content Management (TCM), Total Process and Project Management (TPPM) and Total Stakeholder Management (TSM). The parameter of Total Financial Management (TFM), however, shows negative result in innovation strategy. The study reflects the actual condition of higher education institutions in Indonesia regarding institutional funding and implies that the institution needs to be more innovative in finding suitable and reliable funding resources (apart from regular/yearly institutional budget as being provided by the Indonesian central government) to undertake its major tasks by law, which are [a] education, [b] research and development activities, and [c] the community development-empowerment activities.
\end{abstract}

Keywords - TEDS method; total content management; total financial management; total process and project management; total stakeholder management

\begin{abstract}
Abstrak
Artikel ini bertujuan untuk mengkaji dan mendiskusikan implementasi strategi inovatif pada institusi Pendidikan tinggi di Indonesia. Perangkat Total Evaluation and Decision Square (TEDS) Method, yang terdiri dari [a] Total Financial Management (TFM), [b] Total Content Management (TCM), [c] Total Process dan Project Management (TPPM), dan [d] Total Stakeholder Management (TSM) digunakan sebagai fokus kajian. Kajian inimerupakan studi kualitatif yang disertai pendekatan deskriptif. Data dan informasi dikumpulkan melalui wawancara mendalam pada dekan dan pimpinan fakultas. Hasil wawancara dikaji lebih lanjut dengan menggunakan analisis tematik. Dapat disimpulkan bahwa institusi yang menjadi objek kajian telah menerapkan strategi inovasi yang positif dan bermanfaat. Akan tetapi, strategi dimaksud dinilai belumlah efektif dilaksanakan. Hal ini terlihat dari hasil kajian yang memperlihatkan indikator positif pada Total Content Management (TCM), Total Process dan Project Management (TPPM) dan Total Stakeholder Management (TSM), sedangkan parameter Total Financial Management (TFM) sayangnya memperlihatkan hasil yang negatif. Kajian ini memperlihatkan kondisi actual yang dihadapi oleh institusi perguruan tinggi di Indonesia terkait masalah pendanaan. Konsekwensinya institusi pendidikan tinggi harus jauh lebih inovatif dalam mencari sumber pendanaan yang dapat diandalkan, selain dari anggaran tahunan yang disediakan oleh
\end{abstract}


pemerintah Indonesia dalam rangka melaksanakan tugas utamanya, yaitu [a] Pendidikan, [b] penelitian dan pengembangan, serta [c] pengabdian pada masyarakat.

Kata Kunci - metode TEDS; total content management; total financial management; total process dan project management; total stakeholder management

\section{INTRODUCTION}

The quality of infrastructure in public institution has been one of the major concerns for governments and public institutions as it will directly influence the rate of public satisfaction to use public services provided by the government. Ideally, the quality of infrastructures should continuously be improved and be focused on satisfying public needs. The government should view this as a positive respond to the changing paradigm in providing services for the public. The addition and tremendous rise of technology, in particular the massive use of information and communication technologies/ICT for works, have also made the demand for good infrastructure quality remains evolved every time. Public demand, not only, the high quality and availability of effective and efficient services, but also continuous improvement to the public infrastructures that have been provided by the government.

As a respond to this demand and the phenomenon regarding public infrastructures, most of the government throughout the world have tried to formulate and to implement various innovative strategies that they believe, could be used as sensible patterns and solutions in providing more reliable public infrastructures. The result, however, is still little known whether they are effective and reliable, and further, whether the infrastructures provided have met public expectation in regards on the quality. This situation is also being found in many developing countries, like Indonesia, and specifically in the context of state/government owned higher education institution. The demand for good quality infrastructures in higher education institutions becomes higher and has been a major concern, not only by the government but also by other stakeholders. It is viewed that good quality infrastructures will result of the high quality of students and graduates (Cohen \& Bhatt, 2012). Consequently, governments through their executing institutions and agencies should always prepare and develop innovative strategies in improving and strengthening the quality of infrastructures used by stakeholders of higher education.

However, the problem is still the same. To identify and to measure the most reliable innovative strategies to improve the quality of infrastructures that can meet public demand and expectancy are always difficult and challenging tasks to undertake. This situation is even more difficult and complex in higher education public institutions. As their nature, public higher education institutions should deliver the best standardized skills and education, with various major considerations to take. In many cases, public higher education institution are willing to run and to leap faster by formulating many innovative strategies to improve their infrastructures, but unfortunately, there are circumstances within and surrounding them that have limited their willingness and development plans, in which budget is always a major grievance.

Considering that fact and phenomenon, this study would be interesting and has significant value and contribution to enrich our conceptual and practical knowledge. This study tries to respond to those circumstances by offering a holistic analysis to measure innovation strategies formulated by Indonesian higher education institutions in improving the quality of their infrastructures. The analysis in this study uses the Technical Evaluation and Decision Square (TEDS) Method (Pries-Heje, 2013) as the basis for analysis. As the nature of TEDS, it can detailly figure out the reliability of innovation strategies prepared, decided and implemented by public institutions in improving the quality of infrastructures that they provide for public. A faculty in Universitas Andalas, an Indonesian state-owned university in Padang, Indonesia, was used as the context of the study.

\section{LITERATURE REVIEW}

\section{A. Innovation}

Researchers and scholars have given varying definitions to the concept of innovation. Rogers (2001) for example, defines innovation as an idea, practice or object that is recognized and accepted as a new thing by a person or a group to be adopted. Innovation as a new idea applied to initiate or improve a product or process and services (Robbins, 1994) which will further delivered to the customers. In a more simple understanding, innovation can be meant as creating better products and services (Morris, 2013), which can create values to the 
product among the customers. Therefore, customers and the ability of the product to create value within the customer will be the central themes and consideration if we talked about innovation. In the context of Indonesia, the definition of innovation is understood based on the Law No. 18 year 2002, which says that innovation is a research, development, and/or engineering patterns which aim at developing practical application, value and context of new knowledges, or new ways to apply science and technology that exist in the product or production process.

Innovation can be found in all knowledge and organizational aspects, ranging from product development, management methods, how to do the job and others. Innovation is always a major important subject to be considered by the organization for a long time. Even though we can attract customers' attention by producing new products, but it is more important to consider that innovation and new invention are processes that can determine everything. Innovation in particular, depends on two conditions, namely: [a] freshness and, [b] usefulness in which both of the conditions require effectivity and efficiency. Innovation is one of the most important and most complex issues that are often faced lately. So it can be said that innovation is the key to success for the organization (Tohidi \& Jabbari, 2011)

According to Braslina, Viksne, Upenieks, \& Batraga (2015), there are some factors that can influence success of innovation in an organization, which is:

a) Organizational culture that is formed in the operation and the relationship between complex culture and organizational strategies.

b) Innovatoristic approach, which is an important factor for business success and an essential pre-requisite to have a tendency or a positive attitude in accepting the changes,

c) Organisational planning process to accommodate the ideas through the planning from the past to the future is also one key principle of success. It is important to align short-term decisions with long-term strategy towards continuous product innovation

d) Interaction flexibility process. It is argued that the process of successful innovation in goods and services can raise the interest of consumers. Even in the innovation process there must be an agreement between the research and development, production, and work processes. Thus, the most valuable ideas are implemented in the form of new high added value, once implemented into the workflow design and production of new ones.

e) Human resources. Creativity is one of the most important components in the innovation process, where the best development in the collective process is to involve employees in order to increase the potential for innovation, where employees are viewed as an important element in human capital. An important point that employees are personality, motivation to innovate something new, training, as well as consider the different characteristics of employees.

f) Technology and adaptation. Organization the ability to influence the factors of technology companies, including technology to deploy other types of technical skills and education, and technology strategy is used, thereby increasing innovation and innovative behaviour that not only the internal side but also between organizations.

g) Organizational structure that determines the organization and centralization of its differentiation.

h) Availability of resources. In organizational resources, planning and management of resources which are based on the availability of technology resources are very important. For instance, financial resources are seen as important as to how these resources are managed in the innovation.

i) Knowledge management. The ability of organizations to learn, as well as skills in innovation and knowledge management, should be based on the awareness of both internal and external aspects of organizational knowledge.

From the management perspectives, the management and leadership style are very important factors in affecting staff to create the culture of innovation in the organization. Moreover, both aspects show how they can drive and create the climate of innovation which may further reflect on the culture of organization as a whole. There is a prove that organizations with democratic style are more stable in paving the way for innovative organizations compared with those which experienced autocratic leadership style (Pearson et al., 1989; Roffe, 1999). It is believed and viewed that the leadership of organizations will be a major factor that can determine the climate and the creation of innovative behaviour within people in organizations (de Jong \& den Hartog, 2003). On the other perspective, network with other business organizations can change the attitude of innovation in a positive sense, which indicates that the organization is open to new ideas and to learn from the experiences of other organizations. 


\section{B. Organizational innovation}

If organizations want to be innovative, creative ideas from creative people should be accepted and implemented. Thus, we can estimate that characteristics of the organization together with personal traits of the members of organization will play important roles in improving simulation and innovation (Arad, Hanson, \& Schneider, 1997). There are antecedents in public organization innovation research which include both the environmental and the organizational contexts in which innovations take place, their nature, and also the enabling antecedents and their underlying contingencies (de Vries, Bekkers, \& Tummers, 2015). One main concern regarding the innovation in organization, in particular public institution, is the question which is related to how innovation is created and introduced to the stakeholders of the public institution. Responding to this question and as Moussa, Macmurray, \& Muenjohn (2018), this study considers several factors that can influence innovation in the public institution/sector, which are:

a) Technology procurement is one way of how innovation can be introduced into the public sector. Technology procurement is important for the public sector because of better technology will improve the quality of goods and services produced. However, the transfer of technology to the public sector often require some form of technology development, or at least some adaptation for end users of the technology.

b) Technology development. In the public sector, technology development occurs in large enough quantities, but the development of technology in the concept of innovation is not only the definition. In this context, technology development is understood as the development of new or improved artifacts, production processes, and new forms of work organization or improvement of the level of the individual and systemic level.

c) Reform of the bureaucracy and organization. This is an extension of the interpretation of innovation, which states that the reform is also an innovation. Reform of the bureaucracy and the organization can involve administrative and organizational innovation, conceptual innovation and system innovation interaction.

d) New policy and reform policies in a related concept, policy reforms mean change something to better conditions, and the new policy is a concept that is more open which allows the introduction of a different thing than before. The new policy is often used as the basis of innovation in the public sector.

Braslina, et al., (2015) also further argue that the innovation in the public sector can be divided into several types, are new or enhanced service, process innovation, administration innovation, system innovation, conceptual innovation, and radical rationality changes.

In the context of public sector, organization innovation is viewed important in modern bureaucracies and may accelerate public managerial reforms (Vigoda-Gadot, Shoham, Schwabsky, \& Ruvio, 2005). Despite it is difficult and there are many challenges appear to bring prominent concepts in public sector organizational innovation as a part of public administration reform into realities, but we should not deny that it would be needed to improve the performance of public sector. Public-private sector collaboration in improving public sector performance could be one of the answers to improve innovation in public sector which at the end would impact positively to public administration reform (Cankar \& Petkovšek, 2013). Therefore, the requirement for organizational innovation which could be costly can be shared between public and private institutions as a user of public services provided by public organizations. As Bekkers \& Tummers (2018), innovation in the public sector should be seen as an open process of collaboration between stakeholders across various organizations by which focus and emphasis should be addressed on how to activate stakeholders to join the innovation process.

\section{Innovation strategy}

Hittmár, Varmus, \& Lendel (2013) suggests that the innovation strategy is a basic tool that determines the direction of business innovation. Subramanian \& Nilakanta (1996) previously mentioned that innovation is an enduring nature of which should be continuously carried out by organizations in a certain period. This means that a new innovation will further accelerate the next innovations that will continue to evolve over time. This innovation strategy is mainly based on the business strategy and strategic objective of an enterprises as a business entity. Innovation strategy also helps businesses find new challenges for their development and growth. Strategy innovation is a management concept that consists of many internal and external activities which increase the potential for business innovation.

Innovation strategy is a multidimensional concept which consists of four dimensions: [1] leadership orientation of companies towards innovation (Maidique \& Patch, 1988; Zahra \& Govin, 1993; Tellis \& Golder, 1996), [2] types of innovation that are undertaken by organizations (Betz, 1987; Slack, 2001), [3] source of innovation (Mansfield, 1988; Hogedoorn, 2002) and, [4] the required investment in innovation (Thomson \& Ewer, 1989; Capon, Farley, Hulbert, \& Lehmann, 1992). One main and major innovation strategy that should be particularly 
considered is related to the quality improvement and management facility of the organization. According to Fourie (2006), this includes:

a) Improvement on the quality of infrastructure. The quality of infrastructure related to all phrase that includes improved performance, both from the physical infrastructure and services provided (Fourie, 2006) such as the quality of transport infrastructure, roads and airport runways, timeliness of port services, and safety in the use of rail transport. Therefore, the quality of infrastructure is a condition of the physical infrastructure and the performance of services (Nordas \& Piermartini, 2004). Maintenance will improve the condition of the physical infrastructure, while the performance of the service depends on the capacity of managerial staff or the company's technical capabilities.

b) Improvement on the quality of administration. Subramanian \& Nilakanta (1996) states that the administrative innovation is defined as something that is in the administrative component and affect the social system of an organization. The social system of an organization composes of members of the organization and the relationships among them. This includes rules, roles, procedures, and associated structures for communication and information exchange among members of the organization. Administrative innovation is the introduction of a new system of management, administrative process, or staff development program. An administrative innovation does not provide new products or new services, but indirectly affect the introduction of new products or services or their production processes.

c) Improvement on the quality of technical aspects. Technical innovation is an innovation that occurs in the operating components and influence the technical systems of an organization. Technical systems consist of equipment and operating methods that are used to convert the raw material or information into products or services. A technical innovation, adopt new ideas related to new products or services, or the introduction of new elements in the production process or the operation of the service organization (Subramanian \& Nilakanta, 1996).

d) Quality Improvement of management system. According to Pries-Heje (2013), the quality improvement of management facility can be divided into 3 groups: [a] infrastructure, [b] technical, and [c] administrative. Innovative ways to design begin with a facilities management system that can create a better basis for evaluation and decision-making. There is also a system development within that quality improvement of management facility groups, that include the following aspects; [a] content, [b] processes and projects, [c] finance, and [d] stakeholders. This development system is further called and known as TEDS (Total Evaluation and Decision Square), which is a holistic view in measuring the improvement of management facility which further leads to and determines the innovation strategy of an organization. TEDS itself consists of four model folders, as the following:

1) TFM - Total Financial Management. The total financial management folder evaluates all relevant financial parameters such as logistics costs, internal costs, project costs, restructuring costs, risk evaluation and others.

2) TCM - Total Content Management. The total content management intends to evaluate all parameters which are relevant to the operation of organizations such as the concept of facilities management, emergency concept, the concept of cost reduction, the level of service offered, the service portfolio and others.

3) TPPM - Total Process \& Project Management. The total project and process management intends to evaluate all relevant project parameters such as quality management, time, CAFM (Computer Added Facility Management), the concept of displacement, the initial work, the relevance between the running process and others.

4) TSM - Total Stakeholder Management. Stakeholder folder evaluates all relevant parties who directly and/or indirectly influence organizations such as management, owners, users, staff, law, workers' committee, shareholders, tenants and others.

Therefore, it can be understood that TEDS holistically needs to consider an interaction and synergy of the four model folders (TFM, TPPM, TCM, and TSM). The interaction and synergy of those four in creating TEDS can be seen in the figure 1 as follows. The use of TEDS in this study is reasonable as it is viewed as a holistic view that can simultaneously tie and wrap-up the analysis in the financial management, process and project management, content management and stakeholder management of organizations into one integrative and synergic approach in measuring the innovation strategy of the organization. As a rule of thumb in TEDS, one folder/factor will be regarded as an innovative strategy if it has value of more than $80 \%$ and an organization is considered as in the good condition and has a tendency of experiencing a perfect innovation strategy if all of the four folders/factors get values of more than $80 \%$. 


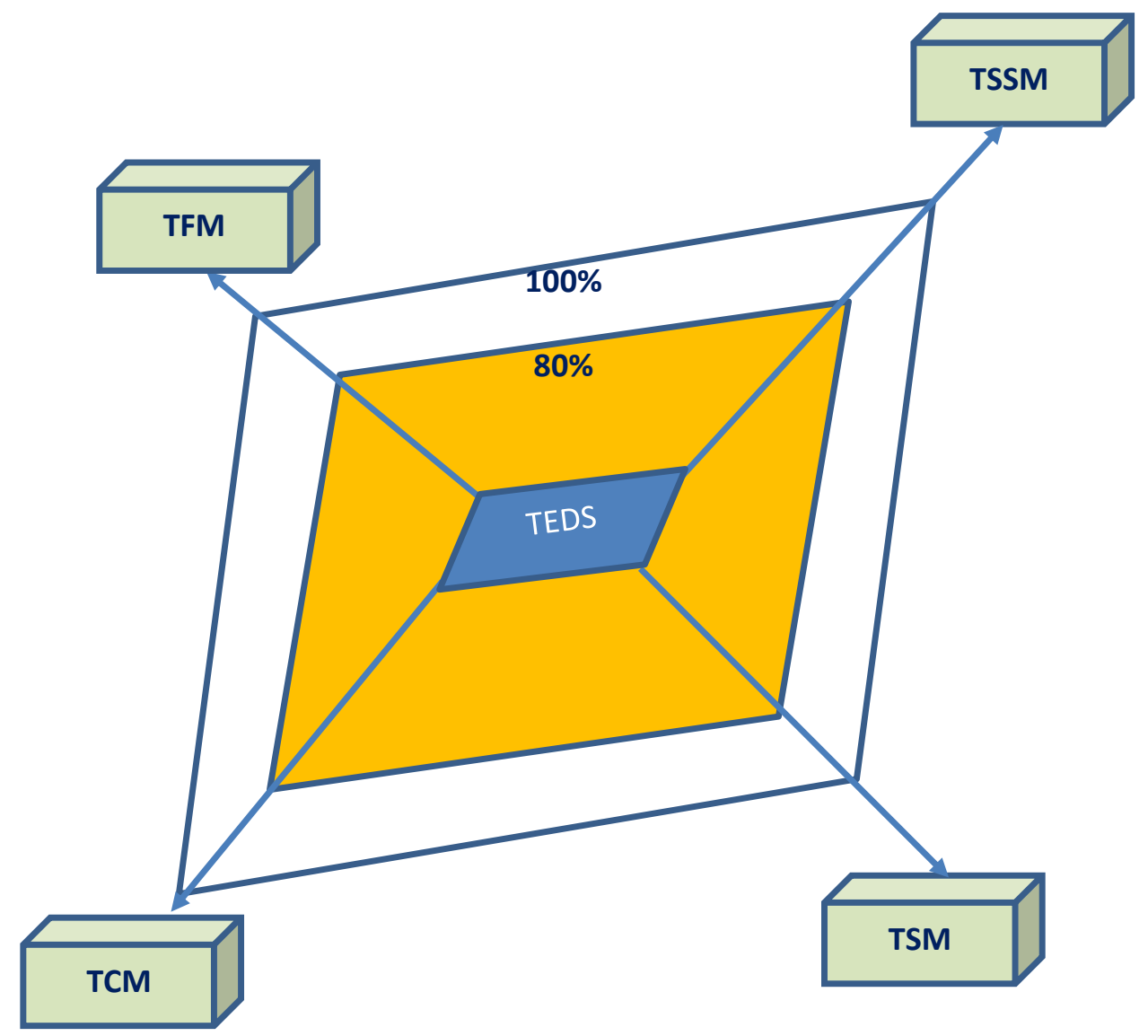

Figure. 1. TEDS and correlations using four models map (Source: Pries-Heje, 2013).

\section{RESEARCH METHODOLOGY AND FrAMEWORK}

The study uses qualitative methodology with exploratory approach and operates thematic and descriptive analysis to measure the TEDS parameters. Data and information were collected by using in-depth interview with informants of the study with the guidance of interview list as the research instrument. Informants of the research are mainly top management of a faculty in Universitas Andalas (dean and vice dean for administration and resources) and top management of the department in the faculty (five head of the departments). Number, type and substance of questions asked to the informant are the same (eighteen questions - but the scopes are different).

This study analyses the innovation strategy undertaken by a specific faculty (anonymously written as Faculty $\mathrm{X})$ at Universitas Andalas in Padang, Indonesia in improving the quality of its infrastructures. This faculty is used as the unit analysis of the study. We use aspects of an innovative strategy, which are: [a] the dimension, [b] the scope, [c] characteristics, [d] reasons, [e] factors, [f] the influence of organizational innovation, and [g] the extent of innovation, as the parameters of construct in this study. For that purpose, the use TEDS method which consists of the following four model map: [a] TFM (Total Financial Management), [b] TCM (Total Content Management), [c] TPPM (Total Process \& Project Management), and [d] TSM (Total Stakeholder Management) is viewed to represent the analysis of the study in order to get insights regarding innovation strategies undertaken by the faculty. The study framework is made circular because we believe, as Subramanian \& Nilakanta (1996), the innovation is an enduring nature that continuously occurs in the organization, in which new innovations within an organization will further generate subsequent innovations in the future. 


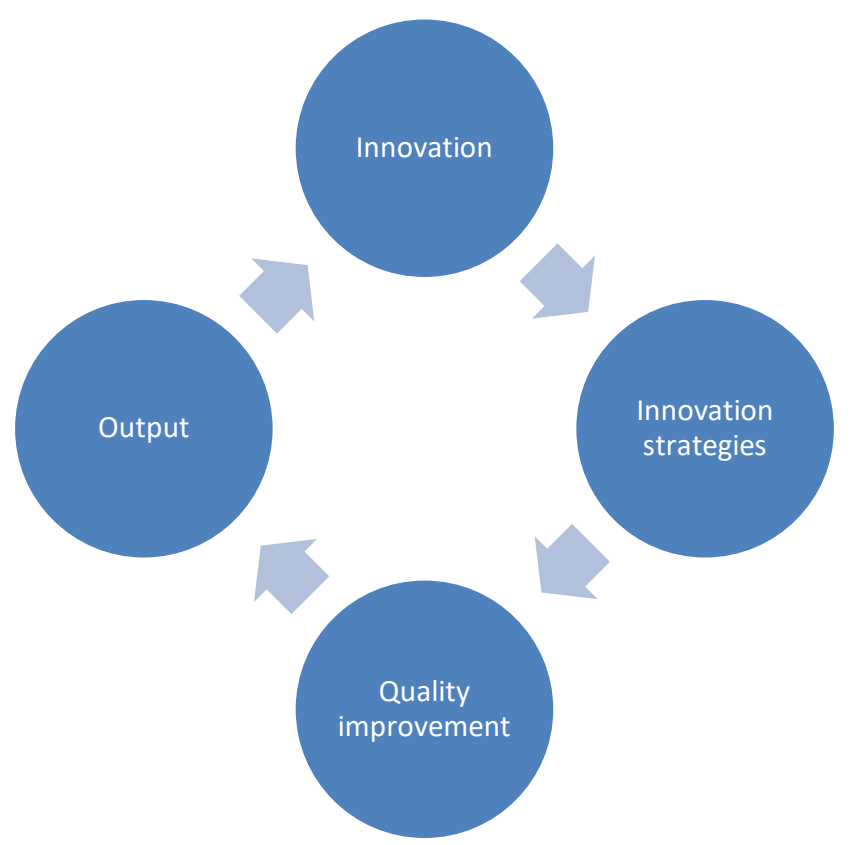

Figure. 2. Research Framework: The Circular Form of Innovation

\section{RESUlTS , FINDINGS AND DiSCUSION}

A. Result

Recalling the previous chapter, this study uses seven informants who are the top management of the faculty (two informants) and the top management of the departments (five informants). Details of the informants in this study shown in the Table 1 .

Table 1. Profile of Informants

\begin{tabular}{clc}
\hline No. & \multicolumn{1}{c}{ Titles } & Level \\
\hline 1. & Dean & Faculty \\
2. & Vice Dean for Administration and Resources & Faculty \\
3. & Head of Department - ME & Department \\
4. & Head of Department - CE & Department \\
5. & Head of Department - IE & Department \\
6. & Head of Department - EE & Department \\
7. & Head of Department - EE & Department \\
\hline
\end{tabular}

All of the informants were chosen based on the consideration that they are having responsibilities and full authorities to improve the quality of infrastructures and facilities in the context of the study. We also viewed that all informants are in the position and have capacities to answer our questions related to the topic of this study. Indepth interview was then arranged with all of those informants in different sequences and schedules, depends on the informants' availability. Data and information obtained from in-depth interview were recorded and the quantitative data which are related to the improvement of facilities in the faculty were documented.

After we analyzed response from our informants and look at to their profiles, we then move to the next stage of analysis, which is to determine the level of TFM, TPPM, TCM and TSM in the context of our study. The study found results of each TEDS factor in the Faculty X of Universitas Andalas as the following.

\section{a) Total Financial Management (TFM)}

The first analysis in TEDS model folders was undertaken in regards of the financial management of the faculty. We identified three types of cost that have usually been borne by the faculty, which are: [a] additional costs, [b] 
transfer costs, and [c] guarantee costs. The major intention and motivation to look at to the parameter of total financial management (TFM) of the faculty is to get an insight and information about the management of costs and finance undertaken by the faculty members as well as how they can use financial resource as one of the resources that can be used and maximized in their institutional innovation strategy.

Our investigation through TEDS-TFM folder found that the faculty has total percentage value of TFM 77\%. This means that the innovation strategy in financial management of the faculty creates $77 \%$ positive impact to the total financial management folder of the faculty's TEDS. Even though that the total costs and additional costs of the institution might have a positive impact (as the percentage value of each is $87 \%$ and $80 \%$ - look at table 2 blow), however in terms of transfer costs and guarantee costs, the financial management strategy undertaken by this institution, can be said, is not innovative at all (as the percentage value of each item is only $72 \%$ and $69 \%$ ). Combination of those four parameters impacted by innovation strategy in financial management is only $77 \%$. Referring to the rule of thumb in TEDS model folder, we further summarize and view that the innovation strategy undertaken by the Faculty X of Universitas Andalas is not innovative - as it just creates $77 \%$ impacts to its total financial management. We can see the result of our finding regarding total financial management as one of the innovation strategies in the faculty as in the table 2 below.

Table 2. Total Financial Management of the Faculty X of Universitas Andalas

\begin{tabular}{lccccc}
\hline \multirow{2}{*}{ TFM - Parameter } & $\begin{array}{c}\text { Significance } \\
1-10\end{array}$ & $\begin{array}{c}\text { Max. Value } \\
\text { col. (A) x 10 }\end{array}$ & $\begin{array}{c}\text { Abs. Value } \\
1-10\end{array}$ & $\begin{array}{c}\text { Weight. Value } \\
\text { col. (A) x (C) }\end{array}$ & $\begin{array}{c}\% \text { Value } \\
\text { col. (D) : (B) }\end{array}$ \\
\cline { 2 - 6 } & (A) & (B) & (C) & (D) & (E) \\
\hline Total costs & 10 & 100 & 8.71 & 87.14 & $87 \%$ \\
Additional costs & 3 & 30 & 8.00 & 24.00 & $80 \%$ \\
Transfer costs & 2 & 20 & 7.21 & 14.43 & $72 \%$ \\
Guarantee costs & 4 & 40 & 6.86 & 27.43 & $69 \%$ \\
\hline Total & & & & $77 \%$ \\
\hline
\end{tabular}

\section{b) Total Content Management (TCM)}

The second finding that has been found is related to the total content management (TCM) of the faculty. By combining four parameters which are [a] facility management concept, [b] emergency concept, [c] level of service, and $[\mathrm{d}]$ reducing costs concept, we found the total result of the innovation strategy in the faculty which impacts its content management is $81 \%$ - as shown in the table 3 below.

Table 3. Total Content Management of the Faculty X of Universitas Andalas

\begin{tabular}{lccccc}
\hline \multirow{2}{*}{\multicolumn{1}{c}{ TCM - Parameter }} & $\begin{array}{c}\text { Significance } \\
1-10\end{array}$ & $\begin{array}{c}\text { Max. Value } \\
\text { col. (A) } \times 10\end{array}$ & $\begin{array}{c}\text { Abs. Value } \\
1-10\end{array}$ & $\begin{array}{c}\text { Weight. Value } \\
\text { col. (A) x (C) }\end{array}$ & $\begin{array}{c}\text { \% Value } \\
\text { col. (D) : (B) }\end{array}$ \\
\cline { 2 - 6 } & $(\mathrm{A})$ & $(\mathrm{B})$ & $(\mathrm{C})$ & $(\mathrm{D})$ & $(\mathrm{E})$ \\
\hline Facility Management Concept & 10 & 100 & 9.07 & 90.71 & $91 \%$ \\
Emergency concept & 6 & 60 & 7.21 & 43.29 & $72 \%$ \\
Level of service & 6 & 60 & 8.07 & 48.43 & $81 \%$ \\
Reducing costs concept & 4 & 40 & 8.21 & 32.86 & $82 \%$ \\
\hline Total & & & & & $81 \%$ \\
\hline
\end{tabular}

Based on the table 3, the highest value of the impact of innovation strategy undertaken by the faculty is related to its facility management concept, which reaches $91 \%$. Other two folders which show the positive impact are the level of service (81\%) and reducing costs concept (82\%). However, the faculty is considered as having low level impact of its innovation strategy which is related to the emergency concept (72\%). The combination of the four folders shows that the faculty is actually has an innovative strategy that creates positive impact to the total content management, where the percentage value reaches $81 \%$. As the rule of TEDS, $80 \%$ is the lowest percentage value which indicates an innovative strategy of an organization.

\section{c) Total Process and Project Management (TPPM)}

The faculty shows percentage value of $83 \%$ in the combination of the impact of innovation strategy undertaken by the faculty to its total process and project management folder. This can be summarized that it has an innovative 
strategy which has brought positive impacts to the total process and project management. Supporting this high percentage value is the impact to [a] quality management, [b] timing, and [c] computer aided facility management/CAFM in which each of the parameter has the percentage value of $90 \%, 92 \%$ and $81 \%$. However, the impact of the faculty's innovation strategy to the delivery concept in its process and project management is very weak, having just scored $68 \%$ in its percentage values. Detailed value of each parameter in this folder is shown in the table 4 below.

Table 4. Total Process and Project Management of the Faculty of X of Universitas Andalas

\begin{tabular}{lccccc}
\hline \multirow{2}{*}{ TPPM - Parameter } & $\begin{array}{c}\text { Significance } \\
1-10\end{array}$ & $\begin{array}{c}\text { Max. Value } \\
\text { col. (A)x10 }\end{array}$ & $\begin{array}{c}\text { Abs. Value } \\
1-10\end{array}$ & $\begin{array}{c}\text { Weight Value } \\
\text { col. (A) x (C) }\end{array}$ & $\begin{array}{c}\text { \% Value } \\
\text { col. (D) : (B) }\end{array}$ \\
\cline { 2 - 6 } & $(\mathrm{A})$ & $(\mathrm{B})$ & $(\mathrm{C})$ & $(\mathrm{D})$ & $(\mathrm{E})$ \\
\hline $\begin{array}{l}\text { Quality management } \\
\text { Timing }\end{array}$ & 8 & 80 & 9.00 & 72.00 & $90 \%$ \\
$\begin{array}{l}\text { Computer Aided } \\
\text { Facility Management } \\
\text { (CAFM) }\end{array}$ & 7 & 70 & 9.21 & 64.50 & $92 \%$ \\
Delivery concept & 6 & 60 & 8.07 & 48.43 & $81 \%$ \\
\hline \multicolumn{1}{c}{ Total } & 2 & & & & \\
\hline
\end{tabular}

The finding of this study infers that the faculty must be aware and improve the delivery concept of its process and project management process. This means that the faculty must improve its approach in transferring the use of new facilities bought from and provided by its vendors and other third parties to the faculty's internal stakeholders, which are mainly the students and lecturers-researchers.

\section{d) Total Stakeholder Management (TSM)}

The total stakeholder management folder is measured based on the combination of the following parameters: [a] the unity of ownership, [b] the unity of management, [c] the unity of legal formal, and [d] the unity of tenants. Total stakeholder management relates to the ability of the faculty to create effective and efficient innovation strategies to communicate and to maintain its relationship with the major stakeholders of the faculty. From table 5 , we can see that the faculty has already had an innovative strategy in communicating and maintaining the relationship with its stakeholders. This is shown in the total percentage value of this folder, which reaches $82 \%$. However, the faculty still needs to increase its innovative approach which can create positive impact to its legal formal matters. The parameter of the unity of legal formal only reaches $74 \%$ - which means that the faculty does not have innovative strategies that can create positive impact to the unity of its legal formal. Details of result from each parameter in this TEDS' folder are shown in the table 5 below.

Table 5. Total Stakeholder Management of the Faculty X of Universitas Andalas

\begin{tabular}{lccccc}
\hline \multirow{2}{*}{ TSM - Parameter } & $\begin{array}{c}\text { Significance } \\
1-10\end{array}$ & $\begin{array}{c}\text { Max. Value } \\
\text { col. (A)x10 }\end{array}$ & $\begin{array}{c}\text { Abs. Value } \\
1-10\end{array}$ & $\begin{array}{c}\text { Weight. Value } \\
\text { col. (A) x (C) }\end{array}$ & $\begin{array}{c}\% \text { Value } \\
\text { col. (D) : (B) }\end{array}$ \\
\cline { 2 - 6 } & $(\mathrm{A})$ & (B) & (C) & (D) & (E) \\
\hline The unity of ownership & 10 & 100 & 8.36 & 83.57 & $84 \%$ \\
The unity of management & 5 & 50 & 8.86 & 44.29 & $89 \%$ \\
The unity of legal formal & 2 & 20 & 7.36 & 14.71 & $74 \%$ \\
The unity of tenants & 3 & 30 & 8.21 & 24.64 & $82 \%$ \\
\hline Total & & & & $82 \%$ \\
\hline
\end{tabular}

\section{e) TEDS Graphic}

Based on the four folders contained in TEDS [TFM, TPPM, TCM and TSM], we can further developed the TEDS graphic for the Faculty $\mathrm{X}$ of Universitas Andalas. The TEDS graphic for this faculty is shown in the figure 3 below.

Figure 3 describes the result of analysis for innovation strategies undertaken by the Faculty of X of Universitas Andalas in order to improve the quality of its facilities. The percentage values which range from $81 \%$ to $100 \%-$ 
or the area in white color means that the organization has innovation strategies that can bring positive impacts in improving its facilities. The percentage value of $100 \%$ indicates that the organization has a perfect implemented innovation strategy which brings positive impact to each parameter of the four folders in TEDS. Meanwhile, the percentage values of $0 \%-80 \%$ or the area in the orange color indicates that an organization is harvesting negative impacts of innovation strategies that have been implemented. Therefore, organizations is recommended and should achieve the percentage value of more than $80 \%$ as the indication of the positive impacts of innovation strategies undertaken by them.

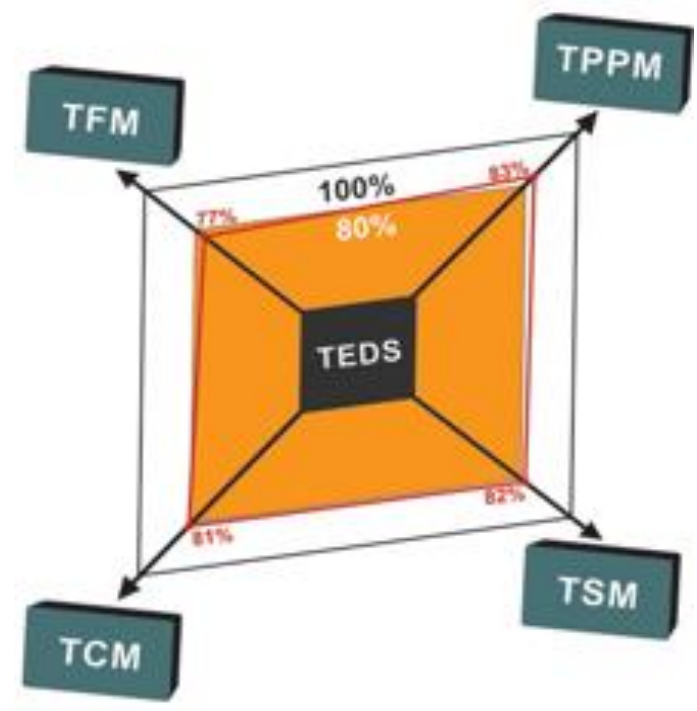

Figure. 3. The TEDS Graphic of the Faculty X of Universitas Andalas

In the case of this study, the impacts of innovation strategies undertaken by the Faculty $\mathrm{X}$ of Universitas Andalas were shown as in the figure 2 above. We can see from the figure 2 that this institution has innovation strategies which has brought positive impacts to TCM [81\%], TPPM [83\%], and TSM [82\%]. Meanwhile, innovation strategies undertaken by this institution has not yet positively created impact to its total financial management issues - the percentage value of this issue is only $77 \%$.

\section{B. Discussion}

\section{a) Total Finance Management (TFM)}

\section{Total cost}

The total cost in the context of the study is defined as all costs received by the faculty from the yearly budget of the university. From the interview with the informant of the study, we know that these costs can be sourced from the university (in terms of non-taxes state revenue/Penerimaan Negara Bukan Pajak-PNBP), the Ministry of Research, Technology and Higher Education/Kemenristekdikti through the Directorate General of Higher Education (shortened in Bahasa Indonesia as DIKTI), grants from external partners of the faculty such as grants A1, A2, A3, TPSDP, and other grants. According to the informant, total amount of funding from all parties for this faculty can reach IDR 10 billion to IDR 12 Billion each year. However, this funding is not significantly increased each year as some departments still received the same amount of funding yearly and even, less than the previous year.

The informants reveal that this is mainly because of the consequence of the consistent number of students enrolled each year. Besides, the minimum amount of grants for this faculty has made it's difficult to establish, to develop/to improve and to maintain facilities required for its operation. As the result of the limited amount of fund and inflexibility to raise fund from external parties, the authority of the faculty cannot maximize its efforts in providing and improving facilities that are actually needed by its stakeholders. So far, the faculty is only limited to raise funding for the improvement and maintenance of the quality of its infrastructures by using the following 
ways: [a] donation and grants from the third parties, such as alumni, [b] marketing of the invention and innovation produced by students, lecturers, and researchers, and [c] establishing business unit belongs to the faculty.

\section{Additional costs}

Additional cost is defined as a part of the whole institutional budget that can be sporadically used by the faculty and its departments in order to tackle emergency needs for funding. In a public organization like the Faculty X of Universitas Andalas, additional costs or can also be recognized as reserved funds should be previously allocated and must be arranged in the yearly budget of the faculty and departments (in Bahasa Indonesia this yearly budget is shortened as RKAKL). There is no funding that can be claimed by the faculty to the rectorate of the university after the RKAKL has been approved and legalized within the university level. This means that the faculty must clearly and carefully defines, identifies and examines its RKAKL because once it is approved and realized, then there will be no more funding provided in the university level to the faculty.

According to the informant, the faculty and its departments have already done its RKAKL yearly. However, they admitted that there is still mis-control and mis-budgeting when they arrange this RKAKL each year. Some departments do not mention the additional costs in their budget (such as the Departments of EE and ME) and some are having less amount than required. This brings consequence, mainly in terms of the difficulties in finding source of fund if there is a sudden or emergency fund to fund the activities in the rolling year. Of course, this impacts some of faculty's and departments' activities.

\section{Transfer cost}

Transfer cost is a budget provided by the faculty and departments to relocate or to remove the existing facilities when they need to change the facilities with the new one. The same case with the reserved fund, this cost should also be carefully allocated and inputted in the RKKL of the faculty. Some of the departments have allocated the budget for this cost, but some are not. For the departments which do not allocate this cost and in the rolling year need remove the facilities, normally they just simply leave the facilities in the existing place and the department just undertake restructuring process of the facilities. Examples for this case is equipment from the laboratories, library or inventory which cannot be more utilize. Since all of these facilities are categorized as the state property, then the removal process should follow the removal procedure as stated by Indonesian government. Normally, the age of facilities in the system of Indonesian financial arrangement is for five years. If the facilities are broken before five years and need to be removed, then the removal process should follow the procedure as stated by Indonesian government.

Considering the long lasting age of these facilities, the faculty and departments have usually never allocated this kind of cost. This has brought consequence related to the difficulties of the faculty to remove the unnecessary and non-utilized facilities, which will at the end, directly or indirectly, influence daily operation of the institution.

\section{Guarantee cost}

Guarantee cost is defined as the cost provided by the faculty or departments which can be sporadically used if stakeholders of the faculty (such as students, lecturers/researchers, users or other stakeholders) got an accident in undertaking their activities, tasks and duties. Our special attention was given to the students as the major stakeholder of the faculty. According to the informant, students in the Faculty X do not have any insurance from accident provided by the faculty. However, the university does provide it since it has been allocated in the university budget.

Recalling findings of the TFM of this faculty, one can understand that the limitation of funding and a more flexible alternative in finding the funding resources are the major challenge that should be faced by this faculty. As de Vries, et al. (2015), organizational innovation always needs sufficient support from the environment and internal organization where it takes place. The limitation of funding and the rigid mechanism in budgeting especially in searching alternative resources for organizational innovation will hinder organizations to move more flexibly in a rapid and dynamic development of higher education management.

Thus, solutions such as public-private collaboration between universities and private sector in funding public sector's organizational innovation will be a reasonable solution that can be chosen by the top management of the faculty and university. As Cankar \& Petkovšek (2013), public-private sector collaboration can be used as a form of solutions that may improve public sector performance. Apart from being the source of funding for organizational innovation, this collaboration will also accelerate reforms in the bureaucracy and organization, 
which at the end, may create good governance mechanism within the faculty and its stakeholders. This will be beneficial to achieve public sector's administration reform.

\section{b) Total Content Management (TCM)}

\section{Facility Management Concept}

The faculty chooses the continuous quality improvement as its major strategy in improving the quality of infrastructures. This strategy is then derived into programs that are related to the quality improvement, including educational quality. Some other programs are:

1) Maintenance of existing facilities

2) Governance of the facilities

3) The use of global standard in the recruitment and management of the facilities, such as the use of supervisors for laboratories, excellent service standard, SOP (standard operating procedures), etc.

However, the faculty realizes that its facility management concept truly depends on the availability of funding. The bigger the funding is, then the better quality of facility management that can be offered and provided by the faculty is. In fact, the quality of facility management concept of the faculty is relatively good and can assist students in undertaking their daily activities which are related with teaching and learning processes. The achievement of some departments (Departments of ME, CE, IE, EE, and EE) which have obtained an A accreditation from Indonesian Higher Education National Accreditation Board/BAN-PT is a prove of this achievement.

Based on achievements of the faculty, we can consider that its facility management concept is very good and this is indicated in the percentage value of its facility management concept which reaches $91 \%$. This further means that the innovation strategy of the faculty has brought positive and significant impact to its facility management concept.

\section{Emergency Concept}

Emergency concept is defined as the facilities which are provided by the faculty for its stakeholders (primarily students, lecturers, researchers, laboratories assistance, administrative employees etc., and can be used to anticipate disasters. Emergency concept of the faculty is implemented by providing evacuation path, emergency ladders, fire extinguishers, and other facilities related to disasters' anticipation.

According to the informant, the existence of facilities for anticipating the disasters is unfortunately not fully available - and some of the facilities are only left as the master plan of the faculty. In fact, the existence of this facility is a must for an organization (standardized). One of the most sophisticated emergency concept provided by the faculty as its innovation strategy is in the form of the earthquake resistant construction design for all of the faculty's building. The faculty has experienced a big earthquake in the previous year which had broken down its buildings. Based on this experience, it designs its buildings with a more sophisticated design. In 2016, the faculty got a grant from Indonesian Agency for Education Endowment Fund for renovation of its buildings.

As the status of the faculty and university is as an Indonesian state-owned institution, therefore all buildings' related maintenance and supplies of the building equipment truly depends on the central government budget. Acquisition and maintenance of facilities in fulfil the emergency concept of the faculty primarily depends on the central government budget. This has brought consequence that the faculty cannot full implement design of its emergency concept and therefore, the innovation strategy of the faculty is considered as not influencing the emergency concept implemented by the faculty. This is proven by the percentage value emergency concept in the TCM folder of the faculty which only reaches $72 \%$.

\section{Level of services provided}

Based on review from Indonesian Higher Education National Accreditation Board (BAN-PT), it has been discovered that utilities and facilities in the faculty are considered as 'very good' - even though it is still difficult to compare with the utilities and facilities provided by the foreign universities. According to the informant, the faculty keeps its efforts in providing and establishing the best utilities and facilities for students as its main user. This is undertaken, for example, by adopting services provided by other more advance universities, by providing new equipment in the laboratories (such as SAM/Scanning Electro Microscoping) and new facilities for student activities etc. The percentage value of level of services provided by the university shows $81 \%$ - which means that the innovation strategy chosen by the faculty has created positive influence to the level of services provided. 


\section{Reducing Costs Concept}

The faculty states the strategy of efficiency as its main reducing costs concept. Even though that the faculty has budget allocation - however it always tries to operate as efficient as possible. Normally, the faculty undertakes a regular management meeting to discuss the possible efficient ways in reducing costs of the faculty as a whole. There is a transparency and fairness principle during the management meeting and the implementation of this concept. So that every department and party can understand about the policies of the faculty.

Reducing costs concept undertaken by the faculty is also implemented by choosing the principle of incremental development of the facilities and by undertaking comprehensive analyses based on the priority of facilities that will be established/developed.

\section{c) Total Process and Project Management (TPPM)}

\section{Quality management}

Quality management is a way that has been chosen by the faculty to manage and to maintain the quality of its facilities. The faculty conducts intensive monitoring and evaluation to look at every existing weakness - then the university's quality assurance board will audit the condition of those existing facilities. The faculty undertakes maintenance of its facilities based on priority system, implementation of standard operating procedures/SOP, continuous controlling system, coordination with internal stakeholders, such as supervisors of laboratory, head of the library, the coordinator of reading room etc. All parties discuss every problem related to facilities in order to find solutions to solve problems.

\section{Time Consumed}

Time consumed is defined as timing that is required by the faculty to undertake innovation in an effort to improve the quality of its infrastructures and facilities. As previously mentioned, the faculty chooses continuous improvement of infrastructures and facilities as its principle, in which reviews will also be undertaken regularly in a long-term period. Therefore, the faculty's principle regarding time consumed in improving and maintaining its facilities and infrastructures also considers scale and priority among facilities and infrastructures that are used for its daily activities and operations. The faculty always reviews which facility and infrastructure that needs to be improved and which one is not. Normally, the one which is prioritized to be improved will need shorter time consumed, in terms of efforts to supply it. This will further improve the quality of services and education provided by the faculty.

\section{CAFM (Computer Added Facility Management)}

The development of sophisticated technology also influences to the faculty. The faculty aware that it should positively respond to the latest development of technology as it will be directly related to services offered by the faculty to its students. In regards of this, the faculty, for example, uses state of the art software for the lectures and for the laboratories. The faculty also provides Wi-Fi to support its students with the social media, which can ease inter-communication between individuals in the faculty.

\section{Delivery Concept}

Delivery concept is undertaken by the faculty to transfer new facilities and infrastructures from vendors into the location of the faculty. However, informant of the study revealed that they mostly do not know how this was undertaken. Several reasons have been revealed, such as: infrequent procurement and unauthorized by the university. Usually, the university undertakes procurement process through its vendors and the faculties, or the departments cannot interfere this process. The faculty just simply convey their needs for facilities and infrastructures and prepares the specifications, and further, they just need to wait until the facilities and infrastructures arrive in their location.

\section{d) Total Stakeholder Management (TSM)}

\section{The Unity of Ownership}

The unity of ownership in the faculty focuses on the students as the major stakeholder of the faculty. The role of students as the stakeholders of the faculty is very big, as they are in the position to [a] improve the faculty's accreditation, [b] maintain the existing facilities, and [c] be responsible during the use of the facilities. Students are also party who can assess the needs for facilities, undertake necessary repairing processes and improvement of the facilities. 


\section{The Unity of Management}

The unity of management is focusing on the management process done by the heads of the faculty and departments. The main and important point related to the unity of management in the faculty is coordination. In doing this, there is a regular management meeting where the management of the faculty and department meet regularly to discuss about everything that is related to the needs of the faculty. The unity of management can also be seen by the principles of the faculty to conduct the principles of good governance, transparency, accountability, openness, and regular auditing process in regards of the activities undertaken by the faculty.

\section{The Unity of Legal}

The unity of legal is a set of permits and legal formal matters that need to be filled up by the faculty or its departments in order to establish or to develop existing facilities, such as building and laboratory equipment. In terms of this, the faculty and departments cannot directly address a permit to the provincial government - but rather than that, using the university as the channel. This means that the university usually acts as a party who applies for the permit to the provincial government regarding the facilities of the faculty. The flow of this procedure and communication has been stated by the university since a long time and the faculty is only positioned as a user who can monitor the progress of this matter.

\section{TheUnity of Tenant}

The unity of tenant is meant as parties outside of the faculty, who wants to cooperate for using the facilities owned by the faculty or its departments. There are several facilities within the faculty that are rented to other parties, but they are not the core business of the faculty. The faculty also offers services to parties outside of the faculty and the most of these services are in terms of laboratory testing, inspection and examination and internships.

\section{CONCLUSION AND IMPLICATION}

This study concludes that the Faculty X of Universitas Andalas has already performed innovation strategies that can stimulate positive impacts to the areas of [a] content, [b] process and project, and [c] stakeholder management. However, there is also a fact shown that this faculty still needs to be aware of the impact of innovation strategies to financial management as the finding suggests that organizational strategies undertaken by this faculty are not yet innovative.

This study further implies that the management of the faculty needs to maintain and to further improve the existing innovative strategies that have stimulated positive impacts to the institution. Other management implication related to this study lies on the policy for financial management, in which it views and believes that the faculty needs to stimulate resources of external funding in order to fund innovative activities and facilities belong to the faculty. This can be done by initiatively incorporating some external funding resources for innovative activities and facilities within the faculty, such as funding from alumni, international organizations, NonGovernmental Organizations (NGOs) and societal institutions (local, national, regional, and international), etc.

A more flexible budgeting regulation in terms of the source of funding for organizational innovation is also required. Public-private collaboration between the faculty and private sectors in funding organizational innovation can be chosen as an alternative solution to solve the problem of limited funding.

\section{REFERENCES}

Alpar, P., \& Reeves, S. (1990). Predictors of MS/OR application in small businesses. Interfaces 20, 2, pp. 2-11.

Arad, S., Hanson, M. A., \& Schneider, R. J. (1997). A framework for the study of relationships between organizational characteristics and organizational innovation. The Journal of Creative Behavior, 31(1), pp. 42-58.

Bekkers, V., \& Tummers, L., (2018). Innovation in the public sector: Towards an open and collaborative approach, International Review of Administrative Science, 84(2), pp. 209-213. 
Betz, F. (1987). Managing Technology: Competing Through New Ventures, Innovations and Corporate Research, Prentice-Hall, Englewood Cliffs, NJ.

Braslina, L., Viksne, K., Upenieks, A., \& Batraga, A. (2015). Innovation process affecting factors in Latvian companies, Regional Formation and Development Studies, 3, pp. 16-26.

Cankar, S. S., \& Petkovšek, V. (2013). Private and public sector innovation and the importance of cross sector collaboration, The Journal of Applied Business Research, 29(6), pp. 1597-1606.

Capon, N., Farley, J. U., Hulbert, J., \& Lehmann, D. R. (1992). Profiles of product innovators among large US manufacturers, Management Science 38, pp. 157-169.

Cohen, D.K., \& Bhatt, M.P. (2012). The Importance of Infrastructure Development to High-Quality Literacy Instruction, The Future of Children, 22(2), pp.117-138

de Jong, J. \& den Hartog, D., (2003). Leadership as a determinant of innovative behaviour; a conceptual framework, Research Report H200303 ERIM, Scientific Analysis of Entrepreneurship and SMEs/SCALES,

de Vries, H., Bekkers, V.J.J.M., \& Tummers, L., (2015). Innovation in the Public Sector: A Systematic Review and Future Research Agenda. Retrieved from SSRN: https://ssrn.com/abstract=2638618 or http://dx.doi.org/10.2139/ssrn.2638618

Fourie, J. (2008). A Note on Infrastructure Quality in South Africa. Development Southern Africa 25(4), pp. 481494.

Halvorsen, T.(2005). On Innovation in the Public Sector. PUBLIN Research Project, pp. 2-21

Hittmár, S., Varmus, M., \& Lendel, V. (2013). Proposal of model for effective implementation of innovation strategy to business, Procedia - Social and Behavioural Sciences 109, pp. $1194-1198$.

Hogedoorn, J. (2002). External sources of innovative capabilities, Journal of Management Studies, pp. 168187.

Maidique, M.A. \& Patch, P. (1988). Corporate Strategy and Technological Policy in Reading in the Management of Innovation. 2nd ed. M. Tushman and W. Moore (eds.), Ballinger Publishing Company, Cambridge, MA.

Mansfield, E. (1988). The speed and cost of industrial innovation in Japan and the United States: external vs. internal technology. Management Science, 34(10), pp. 1157-1168.

Morris, M. (2013). Three dimensions of innovation, International Management Review, 9(2). pp. 5-10

Moussa, M., Macmmurray, A., \& Muenjohn, N., (2018). A conceptual framework of the factors influencing innovation in public sector organizations, The Journal of Developing Areas, 52(3), pp. 231-240

Norda, K. \& Piermartini, R. (2004). Infrastructure and trade. Staff Working Paper, Economics Research and Statistics Division. Geneva: World Trade Organization.

Pearson, G.J., Pearson, A.W., \& Ball, D.F. (1989). Innovation in a mature industry: A case study of warp knitting in the U.K. Technovation, 9(8), pp. 657-679.

Porter, M.E. \& Millar V.E. (1985). How Information You Competitive Advantage. Harvard Business Review, pp. 1-10

Pries-Heje, L. (2013). Integrated Facility Management- Added Value by Innovation, International Journal of Management and Innovation, 5(1), pp. 82-89.

Roffe, I.(1999), Innovation and creativity in organisations: a review of the implications for training and development, Journal of European Industrial Training, 23/4/5, pp. 224-237.

State Secretariat of the Republic of Indonesia. (2002). Law no. 18 of 2002 about the National System of Research, Development and Application of Science and Technology. Republic of Indonesia sheet, no. 84. State Secretariat. Jakarta.

Rogers, E.M. (2001). Diffusion of innovation: A cross-cultural approach, International Encyclopedia of the Social \& Behavioral Sciences, 2nd edition, 8, pp. 378-381.

Robbins, S. P. (1994). Theory and Organization: Structure, Design, and Application, Third Edition, translation by Jusuf Udaya, Jakarta: Arcana

Slack, R.S., (2001). Communications and Media, Edge Hill College, Lancashire-UK 
Subramanian, A., \& Nilakanta, S. (1996). Organizational Innovativeness: Exploring the Relationship Between Organizational Determinants of Innovation, Types of Innovations, and Measures of Organizational Performance, Omega, International Journal Management Science. 24(6), pp. 631-647.

Tellis, G.J., \& Golder, P.N., (1996). First to market, first to fail? Real causes of enduring market leadership, MIT Sloan Management Review, 37(4), pp. 65-75

Thomson, J. H., \& Ewer, S.R. (1989). How Should R\&D Report Its Expenditures?. Research and Development, 31(2), pp. 174-176.

Thong, J.Y.L. \& Yap, C.S. (1995). CEO Characteristics, Organizational Characteristics and Information Technology Adoption in Small Businesses. Omega, International Journal Management Science. 23(4), pp. 429-442

Tohidi, H, \& Jabbari, M.M. (2011). The important of Innovation and its Crucial Role in Growth, Survival and Success of Organizations, Procedia Technology, pp. 353-358.

Vigoda-Gadot, E., Shoham, A., Schwabsky, N., \& Ruvio, A., (2005). Public Sector Innovation for managerial and Post-Managerial Era: Promises and Realities in a Globalizing Public Administration, International Public Management Journal, 8(1), pp. 57-81.

Zahra, S.A. \& Govin, J.G, (1993). Innovation Strategy and Financial Performance in Manufacturing Companies: An Empirical Study, Production and Operation Management, 2(1), pp.15-37. 